\title{
Antioxidant effectiveness of plant cultures
}

\section{Galyna Simakhina, Nataliya Naumenko}

\author{
National University of Food Technologies, Kyiv, Ukraine
}

\section{Keywords:}

Antioxidants

Oxidation

Berries

Herbs

Extraction

\section{Article history:}

Received

18.06.2020

Received in revised

form 17.12.2020

Accepted

25.03.2021

\section{Corresponding} author:

Galyna Simakhina

E-mail:

lyutik.0101@

gmail.com
DOI:

$10.24263 / 2304-$

974X-2021-10-1-6

\section{Abstract}

Introduction. Since the natural antioxidants do not cause any undesirable side effects, they have more preferences in comparison to those synthetic. The objectives of this article are to reveal the plants to be determined as antioxidants' concentrators among the berries and herbs in order to highlight the ways of their practical usage in food technologies.

Materials and methods. Four sorts of cultivated berries and eight species of wild herbs were studied to define their general antioxidant effectiveness. Ten specimens of herbs were examined to reveal the amount and level of bioflavonoids in water-andalcohol extracts experimentally obtained. The amount of ascorbic acid, bioflavonoids, and carotenoids was determined by traditional methods.

Results and discussions. The maximal amount of ascorbic acid $(\mathrm{mg} / 100 \mathrm{~g})$ was revealed in black currants -234 , cherries -62.2 , chokeberries - 129, wild strawberries 104 , blackberries 68.8 . In addition, all the berries listed differ with high amount of bioflavonoids $(\mathrm{mg} / 100 \mathrm{~g})$ - correspondingly, 1858 in black currants; 1340 in cherries; 2460 in chokeberries; 1978 in wild strawberries; 2447 in blackberries. There was observed the natural correlation between the amounts of these two groups of antioxidants in the raw materials researched. This would allow proving the expedience to use them in obtaining the foodstuffs with antioxidant targeting. The ranking of berries alleged as the most utile to correct the amount of ascorbic acid, bioflavonoids, and carotenoids in accordance with recommended daily intakes, looks like this $(\mathrm{mg} / 100 \mathrm{~g})$ : chokeberries -100 , blackberries -2514 , bilberries 2199 black currants 2096, wild strawberries - 2084, cherries 1405.

Relatively high amount of bioflavonoids that act together and henceforth serve as buffer antioxidant system was found in herbs $(\mathrm{mg} / 100 \mathrm{~g})$ : St. John's wort -3.89 , oregano -2.98 , immortelle 2.638 , melissa -1.685 , and thyme -1.470 . Under previously determined indices of the main extraction parameters, 85 percents of bioflavonoids diffused into the extract from St. John's wort; more than 60 percents from black currants, melissa, thyme, salvia, and immortelle; ca 40 percents from oregano; less than 30 percents from nettle and birch. This can be explained by many factors such as different amount of food cellulose, which, in general, affects the bioflavonoid diffusion coefficient during extraction.

Conclusions. The plant raw materials which are endemic for moderate climatic zone - cultivated and feral berries as well as herbs - with high antioxidant content should become the integrate part of foods and drinks elaborated to protect the human organism from harmful free-radical impacts. 


\section{- Food Technology -}

\section{Introduction}

The low-quality foodstuffs eaten by humans, as well as the polluted environment, essentially influence the apparition of free radicals and further proliferation of free-radical processes.

The high reaction ability of free radicals can accelerate the oxidation processes in a live organism and, consequently, lead to the collapse of cellular membranes and their molecular base. This would finally result in numerous pathological states such as oncology diseases (Menshieva et al., 1994), genetically conditioned diseases (Armstrong, 2002), second type diabetes, atherosclerosis, cardiologic insufficiency (Miwa et al., 2008). Therefore, the problem of free radicals and the reaction-capacious oxygen-containing substances is topical for both academic institutions and the society as a whole.

\section{Analysis of the recent scientific works}

The antioxidant substances of various chemical natures (bioflavonoids, ascorbic acid, carotenoids and so on) contained by foodstuffs in different concentrations (Toor et al., 2006; Ishiguro et al., 2007) are believed to resist the expansion of free-radical processes. Whenever such foodstuffs are consumed, the aforementioned substances help to avoid accumulating of free radicals in cells (Backer et al., 2004). Unlike the synthetic pharmacological remedies, antioxidants of biological origin are easily and organically involved into metabolic processes in the organism and, in turn, do not cause undesirable side effects (Simakhina, 2011).

The results of the recent researches in the outlined trend evidence the perspectives of selection of fruit and vegetable cultures or herbs as the sources of antioxidants, regarding the proved ability of the latter to support the immune functions of human's natural antioxidant system (Saura-Calixto et al., 2006), to retard all the stages of free-radical reactions (Van der Sluis et al., 2000), and to provide stabilization of lipids contained by cellular membranes (Samotyja et al., 2007).

Up to nowadays, the majority of scientific works were dedicated to elucidation of antioxidant activity of ascorbic acid, vitamins $\mathrm{A}$ and $\mathrm{E}$, and carotenoids. For instance, there were established the newest facts about the mechanism of biological influence by ascorbic acid (Timirkhanova et al., 2007): particularly, it is the zero C-hypervitaminosis even after its excessive intake in treatment and prevention of many diseases characterized by enhancement of free-radical processes as a consequence of exhaustion of human's natural antioxidant system.

Today, the scientists' attention is more and more drawn to P-active substances of phenolic origin (bioflavonoids, in other words): catechinins, anthocyanins, leucoanthocyanins, flavone glycosides, chlorogenous acid and others. There are many evidences advocating this fact.

Firstly, this group of phenolic compounds is the most wide-spread and represented in maximal concentrations in the certain species of plants. In particular, the authors (Sun et al., 2002) determined high antioxidant activity of feral berries - bog whortleberries, wild strawberries, and bilberries.

Secondly, it is bioflavonoids that are now being studied as the most essential plant-originated biological regulators; in addition, there was proved that fruit or berry pulp, for instance, contains more flavonoids than juices do (Kjersti, 2004).

Finally yet importantly, the key property of bioflavonoids is their ability to regulate the peroxidation syndrome development that is, unfortunately, a universal factor of the pathogenesis of practically all the diseases known and can be activated in any stress or intoxication (Menshieva et al., 2004). 
As the bioflavonoids were predominantly researched in terms of their capability to normalize the capillary penetrability in earlier works (Kjersti, 2004), nowadays, due to the expansion and diversification of the studies, they are going under revelation of the great deal of biological properties. Some of them, particularly, are the ability to regulate the oxidation and restoration processes in the organism (Levitskyi, 2001), to stabilize the cellular membranes (Gordiyenko, 2000), to conduct the preventive action since included into foodstuffs (Voskresensky et al., 2002), to correct the cholesterol amount in the organism (Hässig et al, 1999), and to boost the resistance of live organisms to the malignant environmental factors (Yordanov et al, 2005).

There are many convincing proofs that all of the bioflavonoids' effects listed above are the consequence of their antioxidant activity (Nagendran et al., 2006; Kähkönen et al., 1999), which, in turn, can be determined by the specifications of their composition, precisely the presence of two or more hydroxyl groups in the benzole nucleus of a molecule (Van Acker et al., 1998).

The unique fact is that a great deal of bioflavonoid substances to amplify the biological antioxidant action of each other is contained in the tissues of fruit, berries, vegetables, and herbs (Shkarina et al., 2010).

Antioxidant activity, which is one of the important characteristics of either natural or synthetic compounds, reveals in interception and neutralization of free radicals that appear as a result of physiological processes and hence become capable of attacking the vital targets (Alves et al., 2013). The essential position among the natural sources of biologically active substances belongs to raw fruit and berries (Shestopal, 2011; Simakhina et al., 2016) rich of antioxidant compounds, primarily ascorbic acid and bioflavonoids. Crucially powerful antioxidants are anthocyanins (Mazza et al., 1993; Harborne et al., 2001): upon interaction with the separate free radicals, an anthocyanin imparts the latter a proton and therefore transforms them into a molecular product; in turn, it becomes a weak radical unable to continue the chain reaction (Lashen et al., 2007).

According to the data obtained by Vira Petrova (Petrova, 1986), it is the anthocyanins that contribute to the polyphenolic compound of berries (feral especially), whose main representatives are pelargonidin, cyanidin, and delphinidin. The authors (Stetsenko et al., 2016), having used the HyperChem software (Solovyov et al., 2005) and acquired results of quant-chemical halfempirical calculations (Butyrskaya, 2011), investigated the connections between the electronic structure of anthocyanins and their ability to initiate the mono-electronic reactions with the free radicals. As a result, there was shown that the pelargonidin molecule appears to be the most probable to have a proton split from a hydroxyl group, which would provide the highest antioxidant activity of the substance noticed.

Apart from fruit and berries, the prospective sources of natural antioxidant are herbs that contain the significant amounts of biologically active substances (hereinafter named BAS) capable of variously affecting all the human organs and systems. For instance, they can mobilize the immune system to fight with many harmful factors such as the small radiation doses, stresses, free-radical injuries (Gordon et al., 1994).

Due to the specific biochemical functions of one's body, a human is unable to synthesize the sufficient portions of these substances or at least possesses them in a limited amount. Thenceforth, the main antioxidants (like ascorbic acid, bioflavonoids, carotenoids and so on) should be consumed with food - raw fruit and berries or the final foodstuffs fortified with BAS complexes extracted from herbs. The plant-originated ingredients are able to act in synergy, which fact proves the expedience to extract not a single component, but a complex of BAS from herbs. The scientific experience shows (Chekman, 2000) that it is more facile for the complexes, unlike for the simplex substances, to harmonize the system of active and auxiliary substances to increase their 
antioxidant activity and, correspondingly, to empower the functions of human natural antioxidant system.

The topicality of the problem under discussion can be confirmed by the results of numerous researches on elaboration of the methods to obtain the natural antioxidants, which may be categorized into two large groups.

The first group scientists aim their work at the extraction of the certain single substances (ascorbic acid, rutin, quercetin, dihydroquercetin, chlorogenous acid and others).

The second group scientists tend to obtain some other BAS in the complex with phenolic substances (ascorbic acid, organic acids, carotenoids etc.)

The first trend can be epitomized by the method of rutine obtaining proposed by A. Kosyan (2006, Ukrainian patent UA 12544). This method belongs to glycoside chemistry, particularly to separation and purification of vitamin preparations from plant raw materials. What make it attractive to the scientists are its ecological purity, safety, relative cheapness and technological expedience.

Besides, there is also an interesting method to obtain the flavonoids from plant raw materials proposed by A. Sampiyev et al. (Sampiyev et al., 1999). It is intended to use the following species of herbs: Herba polygoni, Herba leonuri, Sofora iaponica, Scutellaria baikalensis.

What appears to be quite expedient is the method by L. Igrunov (2005, Ukrainian patent UA 10365), elaborators of which propose to use oat straw or hull for the raw material to be further extracted by water-and-alcohol solution during 1-3 hours with a temperature of $40-98{ }^{\circ} \mathrm{C}$.

The usage of the complex extracts makes possible to intensify the process, to increase the purity grade of the target products, and to raise the output of biologically active substances. For instance, the method to obtain an antioxidant from bearberry leaves (N. Bila, 2006, Ukrainian patent 16774) is based on the raw material extraction in the direct electric field by 1-percent water solution of acetic acid with addition of Twin-80 surfactant.

N. Hrybova et al. (2008, Ukrainian patent 33578) proposed the method to obtain an antioxidant from bearberry leaves by ultrasound extraction with a constant impact of ultrasonic waves (frequency of $60 \mathrm{kHz}$ ) during 100 minutes in a room temperature. This method is believed to increase the general flavonoid output and reduce the time of extraction process.

On the other hand, the usage of ultrasound may have some negative consequences due to destruction of phenolic compounds, resulting from distribution of ultrasonic waves within a system.

The method to obtain the biologically active extraction from plant raw material under low temperatures (O. Osetsky et al., 2000, Ukrainian patent 32028) is considered interesting and relevant in terms of theoretical substantiation.

There has been already noticed that the range of authors set the objectives to extract some other substances together with phenolic complexes (for instance, vitamin $\mathrm{C}$, organic acids, amino acids etc.). This can be epitomized by the method to obtain the natural antioxidant from oak bark (L. Danilova et al.) (Danylova et al., 2016). The authors of this work widened the array of plant raw materials from which the antioxidant complexes may be attained, and their main conclusion is that the target products (as mono compounds) are expedient to be used in pharmacy, and the BAS complexes in food industry, regarding their synergistic action towards each other.

Despite the fact that the researches on the BAS of fruit, berries and herbs initiated in 19601970s (Chekman, 2000; Petrova, 1986), the authoritative data about their antioxidant activity and the amounts in various sorts of plants have not been systematized yet. This may limit the range of their usage on food technologies and elaboration of the new food products with antioxidant trend. Therefore, blocking of free radical processes, which are triggered with active oxygen forms, on the starting stages would finally abate. Finally yet importantly, the effective methods to obtain the 


\section{- Food Technology —}

BAS complexes with antioxidant action, oriented at involvement of cheap raw materials and accessible technological equipment, are still under design.

The objectives of this research are to reveal the concentrators of antioxidants (ascorbic acid, bioflavonoids and carotenoids) among fruit, berries and herbs, to study the grade of bioflavinoid transition from raw herbs into water-and-alcohol extract, and to determine the trends of their practical usage in food technologies.

\section{Materials and methods}

\section{Plant raw materials}

Cultivated sorts: cherries, raspberries, black currants, red currants. Feral species: chokeberries, bilberries, blackberries, guelder, cranberries, cornel, gooseberries, wild strawberries.

Herbs: nettle (Urtica), oregano (Origanum vulgaris), melissa (Melissa officinalis), thyme (Satureja hortensis), salvia (Salvia officinalis), blossoms of St. John's wort (Hypericum perforatum l.), leaves of birch (Betula pubescens), blossoms of chamomile (Chamomilla recutita), leaves of salvia (Salvia), dead nettle (Herba leonuri), blossoms of immortelle (Helichrysum arenarium l. Moench.).

All the berries selected were assessed to define the amount of ascorbic acid, bioflavonoids, carotenoids and, correspondingly, the general antioxidant activity of each of the culture in terms of their further usage in antioxidant foodstuffs production. Owing to the fact that cultivated berries and their feral analogues differ with the correlations of essential biocomponents as a consequence of the conditions of their growth and far higher resistance of feral plants to malignant environmental factors, the mentioned raw materials were studied separately.

\section{Obtaining the extractions}

The dried raw materials (leaves and blossoms) with humidity of 10-12 percents were used to obtain the herbal extractions (Sampiyev et al., 1999). The water-and-alcohol extractions were obtained by counter-flow extracting until the amount of dry substances reached 15-18 percents, depending on the sort of raw (Chuyeshov et al., 2002).To establish the optimal indices of the main parameters of herb extraction process, the impact of the factors like dispersion level, extraction duration, correlation between raw material and the extracting substance, and alcohol concentration in the extracting substance on bioflavonoid output was studied. Since the herbal raw material was represented only by leaves and blossoms (solid parts like roots and stems were not taken into account), the selection of the optimal extraction conditions was based on the analysis of St. John's wort blossoms (Sampiyev et al., 1999).

\section{Vitamin C determination}

Vitamin C is one of the main antioxidants in fruit and berries (Petrova, 1986). The method of its extraction is traditional, based on the usage of sodium 2.6dichlorphenolindophenolate (Dadali et al., 2003) 


\section{Bioflavonoids determination}

The amount of bioflavonoids was determined by the general colorimetric method based on formation of flavonoid-and-aluminum complex (Wang et al., 2007).

\section{$\beta$-carotene determination}

The amount of carotenoids was determined by the general method based on the extraction of carotene with addition of organic solvents, and further measuring optical density of the solution on the spectrophotometer (Juntachote et al., 2005).

\section{General antioxidant effectiveness index}

This index (hereinafter GAE) was determined regarding the general amount of ascorbic acid, bioflavonoids and carotenoids (Santos et al., 2019).

\section{Results and discussions}

\section{General antioxidant effectiveness of fresh berries}

Fresh fruit and berries as well as the frozen half-products on their base are the main source of essential BAS, first of all the vitamins - antioxidants, bioflavonoids and carotenoids (Ukrayinets et al., 2019) The results of estimation of the raw materials in terms of antioxidant amounts are presented in Tables 1 .

Table 1

General antioxidant activity of cultivated berries, $\mathrm{mg} / 100 \mathrm{~g}$

\begin{tabular}{|c|c|c|c|c|c|c|c|c|c|c|}
\hline \multirow[t]{2}{*}{ Specimens } & \multicolumn{3}{|c|}{ Ascorbic acid } & \multicolumn{3}{|c|}{ Bioflavonoids } & \multicolumn{3}{|c|}{ Carotenoids } & \multirow[b]{2}{*}{ 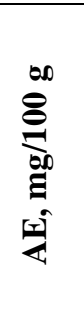 } \\
\hline & 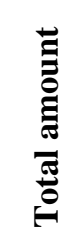 & 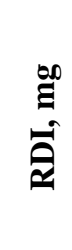 & 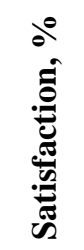 & 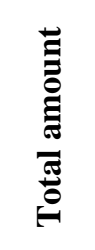 & $\begin{array}{l}\stackrel{00}{\Xi} \\
\hat{a} \\
\hat{a}\end{array}$ & 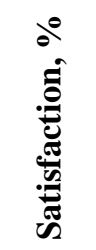 & 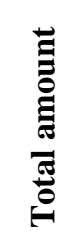 & $\begin{array}{l}\stackrel{600}{\Xi} \\
\overrightarrow{\mid \vec{a}}\end{array}$ & 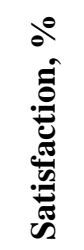 & \\
\hline Cherries & 62.2 & 200 & 31.1 & 1340 & 500 & 268 & 2.4 & 6 & 40 & 1405 \\
\hline Raspberries & 51.4 & 200 & 25.7 & 1285 & 500 & 257 & 1.2 & 6 & 20 & 1338 \\
\hline Black currants & 234 & 200 & 117 & 1858 & 500 & 372 & 2.8 & 6 & 63.3 & 2096 \\
\hline Red currants & 49.4 & 200 & 24.7 & 1305 & 500 & 261 & 1.15 & 6 & 23 & 1356 \\
\hline Chokeberries & 129 & 200 & 64.5 & 2466 & 500 & 493.2 & 4.9 & 6 & 81.6 & 2600 \\
\hline Bilberries & 54.6 & 200 & 27.3 & 2143 & 500 & 428.6 & 1.4 & 6 & 23.3 & 2199 \\
\hline Blackberries & 68.8 & 200 & 34.4 & 2447 & 500 & 489.4 & 1.57 & 6 & 26.4 & 2517 \\
\hline Guelder & 39.4 & 200 & 19.7 & 1345 & 500 & 269.0 & 1.7 & 6 & 28.3 & 1386 \\
\hline Cranberries & 36.6 & 200 & 18.3 & 1076 & 500 & 215.0 & 0.56 & 6 & 9.3 & 1113 \\
\hline Cornel & 31.2 & 200 & 15.6 & 373 & 500 & 74.6 & 1.1 & 6 & 18.4 & 405 \\
\hline Gooseberries & 55.8 & 200 & 27.9 & 876 & 500 & 175.2 & 1.18 & 6 & 19.7 & 933 \\
\hline Wild strawberries & 104 & 200 & 52 & 1978 & 500 & 395.6 & 1.35 & 6 & 22.5 & 2084 \\
\hline
\end{tabular}

Notes: RDI - recommended daily intake (MOZ, 2017); AE - antioxidant effectiveness. 
The researched cultivated sorts and wild species have quite high amount of ascorbic acid and bioflavonoids. As it was expected (Petrova, 1986), the bioflavonoid content in feral berries is far higher than in those cultivated. For instance, the grade of satisfaction the daily need in bioflavonoids is from 257 до 372 percents for cultivated plants (MOZ, 2017) whereas in feral berries this index oscillates from $74.6 \%$ to 493.2 percents (MOZ, 2017). Therefore, all of the cultures researches were taken into consideration as the raw materials rich in bioflavonoids, meantime cornel and gooseberries were omitted from this list due to low bioflavonoid content.

With a few exceptions, the correlation between the amount of ascorbic acid and bioflavonoids is different for each sort of raw materials. As Vira Petrova asserted (Petrova, 1986) the dynamic balance in such a system may remain stable only under the certain concentration correlations between flavonic compounds and ascorbic acid. Whenever the concentration of any compound changes, it would cause the shift of the balance into one or another side to weaken the stabilizing factor of both vitamins relatively to each other and, in turn, to lower their antioxidant effect.

The third factor to evaluate the antioxidant activity of raw berries was the content of carotenoids. Generally, berries cannot be related to plentiful carotenoid sources, except of some sorts of eglantine, hawthorn, chokeberries, rowan and sea-buckthorn. The author of the monograph (Petrova, 1986) indicate that the maximal amount of carotenes is contained in ripen berries; what is more, this group of BAS is accumulating unevenly. This can be explained by the fact that the berries have a certain concentration of BAS formed at the first stage of growth; from thence, it slightly lowers and thereby sharply flashes up to the time of full ripening.

According to data obtained in our researches, most of carotenoids is contained in chokeberries $(4.9 \mathrm{mg} / 100 \mathrm{~g})$, black currant $(3.8 \mathrm{mg} / 100 \mathrm{~g})$, cherries $(2.4 \mathrm{mg} / 100 \mathrm{~g})$, guelder and blackberries $(1.7 \mathrm{mg} / 100 \mathrm{~g}$ and $1.57 \mathrm{mg} / 100 \mathrm{~g}$ correspondingly).

Regarding the tables 1 and 2, feral berries (apart from cranberries, cornel and gooseberries) have their GAE higher than in cultivated sorts. Particularly, the maximal index of activity is $2,096 \mathrm{mg} / 100 \mathrm{~g}$ of the final product for black currants, whereas for wild-grown chokeberries it reaches $2,600 \mathrm{mg} / 100 \mathrm{~g}$ of the final product. This tendency allows confirming the results obtained by other scientists (Petrova, 1986; Mazza et al., 1993). Overall, the descending sequence of GAE in cultivated berries looks like this:

\section{Black currant $>$ Cherries $>$ Red currants $>$ Raspberries.}

For feral berries, the sequence is the following:

$$
\begin{gathered}
\text { Chokeberries }>\text { Blackberries }>\text { Bilberries }>\text { Wild strawberries }>\text { Guelder }> \\
>\text { Cranberries }>\text { Gooseberries }>\text { Cornel. }
\end{gathered}
$$

The recommended daily intakes of the antioxidants researched are $500 \mathrm{mg}$ for bioflavonoids (MOZ, 2017), $200 \mathrm{mg}$ for ascorbic acid (MOZ, 2017), $6 \mathrm{mg}$ of carotenoids (MOZ, 2017); total amount is $706 \mathrm{mg}$ (MOZ, 2017). Besides, all the substances should be consumed altogether because only in combination can they make a positive effect (Spirichev et al., 2003). Therefore, quite important is the early substantiated presence of the studied antioxidants in the amounts manifold exceeding the RDI: namely, $100 \mathrm{~g}$ of chokeberries - in 3.68 times, $100 \mathrm{~g}$ of black currants - in 2.97 times.

Starting from the RDI of the studied antioxidants as well as the grade of their accumulation in berries, it is decidedly expedient to relate some of them, which have their 
GAE of $1400 \mathrm{mg} / 100 \mathrm{~g}$ of the final product and more (to twice exceed the RDI), to natural antioxidant concentrators, and thereinafter to select the berries for obtaining the foodstuffs of antioxidant destination in both the various branches of food industry and restaurant households, according to the principles presented in Figure 1.

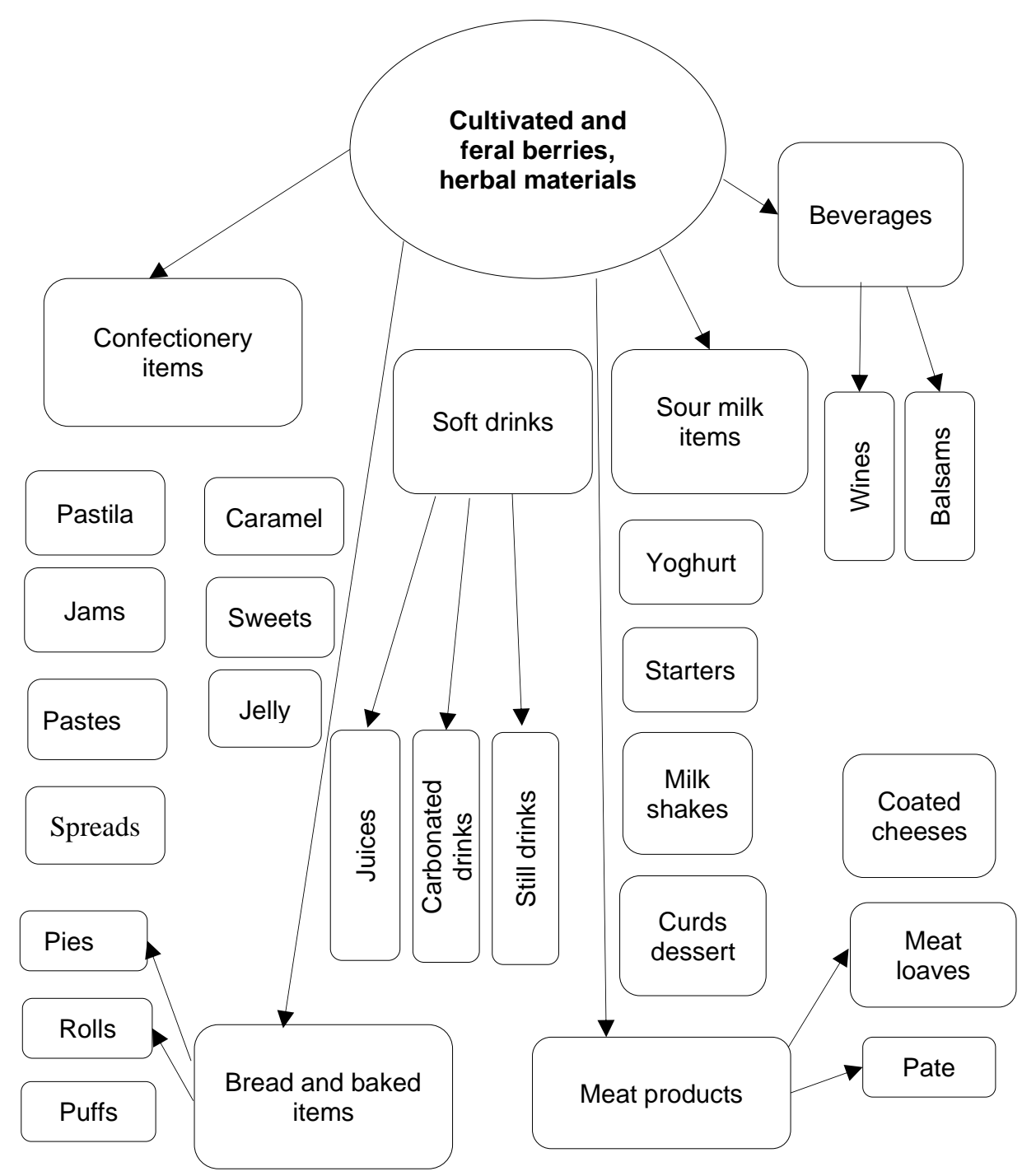

Figure 1. Assortment of foods and drinks with antioxidant destination using the plant raw materials

Certainly, the proposed trends of natural antioxidant usage cannot be limited by the listed options. For instance, the optimal solution to the problem of exploiting the antioxidant 


\section{Food Technology}

properties of plant raw materials was implemented by the authors (Robert et al., 2010), which is incapsulation of pomegranate juice alcohol extractions into malt-dextrin capsules with a help of spray drying technology.

The authors (Rozek et al., 2010) proposed the method of adding the industrially produced phenolic extraction from grapes, which were obtained by osmotic procession of grape seeds and white grape mash, into different food bases.

Lipophilic bioflavonoid (rutine) derivatives, due to their capability of capturing the free radicals and retard the lipid peroxide oxydation (in other words, revealing the antioxidant properties) are also recommended to protect the foodstuffs from oxidation. Bioflavonoids (namely quercetine) can be extracted from onion husk in the supercritical state (Ko Min-Jung et al., 2011), on the basis of which the possibility to substitute the organic solvents by water in food technologies is proved properly.

Henceforth, selection of the raw materials with high antioxidant activity, methods of natural antioxidant obtaining and spheres to use them are being elaborated and improved, regarding the constant threat of uncontrolled free-radical processes and the necessity to neutralize them.

\section{Process of bioflavonoid extraction from herbal raw materials}

Herbs are used to treat the diseases in humans and animals either directly or as a raw material for chemical and pharmaceutical industry (Chekman, 2000). Among 100,000 medicines well-known in the world, circa 30,000 are produced from plants (WHO, 1998). According to the WHO, 10,000 species of herbs are exploited with medicinal purposes in 73 high economically developed countries (WHO 2004). Scientists are discovering the new BAS, widening the nomenclature of their existing groups, searching the possibilities to complexly use both the entire plant and its separate parts. The great deal of plant-originated substances reveals their ability to synergistic action (Pezzani et al., 2019). Along with that, the usage of herbs in production of foods for mass and special consumption is rapidly proliferating (Dadali et al., 2003). For example, it has become a tradition to add the various made of fruit, berry and herbal half products into confectionery items; on the other hand, many recipes with additives of herbs - like ginseng, chamomile, marigolds etc. - in different aggregate states (powders, water, alcohol, ether extractions, purees) for fortification of food bases (Spirichev, 2003). Herbal BAS are confirmed to be congenial to human organism; therefore, as a constituent of easily absorbed food complexes, they are the essential link of the structure and effective functioning of human organism systems, including the one of antioxidant protection (Levitskyi, 2011).

While fruit and berries may be consumed directly or as half products to enrich many foodstuffs, herbal raw materials is being prepared in the form of water and water-and-alcohol extractions, condensed and pastous concentrates etc. (Dekebo, 2021). However, the antioxidant properties and antioxidant effectiveness of herbs is still studied sporadically (Gromovaya et al., 2008). Hence, this part of the article is dedicated to researches on extraction of herbal raw materials and elucidation of the conditions for maximal diffusion of bioflavonoids into the extract as the factor to characterize the antioxidant effectiveness of the latter (Shkarina et al., 2010). In studying the herbal materials, the main attention was paid to phenolic substances regarding their curative effect, particularly because they can easily create the complex compounds of flavonoids and metal ions (Simakhina, 2011).

Dispersion analysis showed the impact of the researched factors to define the effectiveness of extraction on the bioflavonoid output (Table 2).

Table 2 
Influence of conditions to extraction of St. John's wort blossoms on bioflavonoid amount in the extract, $\mathrm{mg} / 100 \mathrm{~g}$

\begin{tabular}{|c|c|c|}
\hline № & $\begin{array}{l}\text { Extraction } \\
\text { conditions }\end{array}$ & $\begin{array}{c}\text { Bioflavonoid } \\
\text { amount, } \mathrm{mg} / 100 \mathrm{~g}\end{array}$ \\
\hline 1 & $\begin{array}{l}\text { Dispersion of the material, } \\
\text { mm } \\
1 \\
3 \\
5 \\
7 \\
\end{array}$ & $\begin{array}{l}3.22 \\
3.26 \\
2.87 \\
2.46\end{array}$ \\
\hline 2 & $\begin{array}{c}\text { Alcohol percentage in a } \\
\text { water-and-alcohol solution } \\
0 \\
30 \\
50 \\
70 \\
95\end{array}$ & $\begin{array}{l}0.64 \\
2.75 \\
2.92 \\
3.24 \\
1.22\end{array}$ \\
\hline 3 & $\begin{array}{c}\text { Proportion between raw } \\
\text { material and an extracting } \\
\text { substance } \\
1: 5 \\
1: 10 \\
1: 15\end{array}$ & $\begin{array}{l}2.59 \\
3.28 \\
3.21 \\
\end{array}$ \\
\hline 4 & $\begin{array}{c}\text { Extraction duration, } \\
\text { minutes } \\
30 \\
60 \\
90 \\
120\end{array}$ & $\begin{array}{l}2.44 \\
2.62 \\
3.26 \\
3.28\end{array}$ \\
\hline
\end{tabular}

Since BAS of herbs mostly belong to thermo labile substances (Wills et al., 2000) extraction was conducted with a temperature of $35-40{ }^{\circ} \mathrm{C}$. There was confirmed that the bioflavonoid amount in extractions from raw materials with particle dispersion of $1-3 \mathrm{~mm}$ is practically identical, but in case of larger particle size it lowers by 12 percents. The optimal concentration of alcohol in water-and-alcohol solution is averred 70 percents, on account of the fact that in 30 percents and 50 percents the rate of extracted bioflavonoids is lower, correspondingly, by 15 percents and 11 percents.

In water extraction, it was only 6 percents of bioflavonoids to diffuse into the extract. The mitigation of bioflavonoid output after extraction by pure alcohol can be explained by the fact that the significant amount of bioflavonoid substances transformed into constrained state. The largest part of bioflavonoids was extracted in proportion between the raw material and extracting substance of 1:10 and 90-minute duration of the process.

These results complement the information presented in (Inglett et al., 2011), which affirmed that far higher output of bioflavonoid substances is provided after extraction of plants by 70-percent water-and-alcohol solution than by water or absolute alcohol. 
Statistical procession of the attained results evidences that the average relative error with probability of 95 percents is defined as $3.6 \%$. Therefore, the further researches were accomplished with the following parameters: dispersion of herbal particles $-1-3 \mathrm{~mm}$, alcohol concentration in water-and-alcohol solution -70 percents, Proportion between raw material and an extracting substance $-1: 10$, duration of the process -90 minutes, temperature of the process $-35-40^{\circ} \mathrm{C}$.

The results of our researches are presented in Table 3 according to the descendant index of bioflavonoid extraction from 10 kinds of herbs.

Percentage of extraction of bioflavonoids from plant raw materials

Table 3

\begin{tabular}{|l|c|c|c|c|}
\hline \multicolumn{1}{|c|}{ Raw materials } & \multirow{2}{*}{$\begin{array}{c}\text { Optical } \\
\text { density, }\end{array}$} & \multicolumn{2}{c|}{$\begin{array}{c}\text { Bioflavonoid } \\
\text { amount/100 g }\end{array}$} & \multirow{2}{*}{$\begin{array}{c}\text { Bioflavonoid } \\
\text { extraction } \\
\text { percentage }\end{array}$} \\
\cline { 3 - 4 } & units & In raw & In potions & \\
\hline 1. St. John's wort blossoms & 0.38 & 3.890 & 3.286 & 84.48 \\
\hline 2. Black currant leaves & 1.68 & 1.281 & 0.885 & 69.06 \\
\hline 3. Melissa leaves & 0.49 & 1.685 & 1.159 & 68.81 \\
\hline 4. Thyme leaves & 1.53 & 1.470 & 0.996 & 67.74 \\
\hline \multicolumn{1}{|c|}{ 5. Salvia leaves } & 1.42 & 0.634 & 0.409 & 64.62 \\
\hline 6. Immortelle blossoms & 1.88 & 2.638 & 1.702 & 64.52 \\
\hline 7. Oregano blossoms & 1.72 & 2.980 & 1.175 & 39.44 \\
\hline 8. Chamomile blossoms & 1.44 & 0.472 & 0.139 & 29.46 \\
\hline 9. Dead nettle herb & 1.44 & 0.462 & 0.132 & 28.63 \\
\hline 10. Birch leaves & 0.47 & 0.825 & 0.203 & 24.62 \\
\hline
\end{tabular}

As a result of the researches, there were determined the amount of bioflavonoids in raw herbs and the expedient concentrations of their extractions (potions). Additionally, it was stated that in case of optimal conditions of the process, the bioflavonoids are believed to diffuse completely into the extraction. For example, bioflavonoid extraction percentage is 84.46 for St. John's wort blossoms, and about 69 for leaves of black currant, melissa, thyme, salvia, and for immortelle blossoms. Talking about the other species of plants, the bioflavonoid output lowers to 24 percents (birch leaves) Such a range of the absolute indices of bioflavonoid amount in extractions may be explained to the certain extent by differences in tissue structure and biocomponent composition of various plants, which fact can impact the diffusion coefficient. All of the researched plants have different grade of antioxidant effectiveness that can be conditioned by bioflavonoid amount. According to this index, we composed a scale of their comparative assessment:

\section{St. John's wort $>$ Oregano $>$ Immortelle $>$ Melissa $>$ Thyme $>$ Black currants $>$ $>$ Birch > Salvia > Chamomile $>$ Nettle}

Thenceforth, the first five of this scale are alleged to be the most effective out of the herbs researched, so they would be widely and successfully used in production of foods and drinks with antioxidant action as the constituents of a diet minimizing toxic influence of freeradical processes on human organism (Kähkönen et al., 1999). Last but not least, these plants are expected to occupy their place in medical practice, particularly in antioxidant therapy (Menshieva et al., 1994). 


\section{Conclusions}

1. All the biologically active substances, which are necessary for normal vital activity of a human, are consumed with food, drinks and herbal remedies and are further biologically transformed, digested and absorbed. In transformations into structural and functional cellular elements during metabolic processes, BAS provide the mental and physical endurance of the organism; determine one's state of health and workability. The lack of certain biological components in a diet inevitably leads a human to detrimental consequences.

2. Within the variety of biologically active substances, the significant group is comprised by antioxidants such as ascorbic acid, bioflavonoids and carotenoids, which are able to block the harmful free-radical processes in human organism. The latter are usually triggered by the excessive amount of active oxygen forms damaging the molecules of proteins, nucleic acids, cellular membranes etc. and therefore causing different pathologies.

3. The raw berries and herbs are the plentiful natural source of antioxidants, which statement may be proves by our results of researches on their biological composition. In our insight into biological systems, human organism primarily, we can predict that foods produced with the usage of berries and herbs (the natural antioxidant concentrators) would demonstrate the proper antiradical activity by decreasing of the level of hydroxyl radicals that are the most reactively capable intermediates of oxygen restoration in the system; along with that, they would reveal the antioxidant properties in blocking the peroxide oxidation processes. In a nutshell, quite a topical, prospective, and precisely oriented at amelioration of human health is the problem of elucidating the chemical composition of widespread and unknown kinds of domestic plants, inquiries of the new sources of antioxidants with their further application to obtain the wide array of antioxidant foodstuffs.

\section{References}

Alves A., Ramos A., Goncalves M.M. et al. (2013), Antioxidant activity, quality parameters and mineral content of Portuguese monofloral honeys, Journal of Food Composition and Analysis, 30(2), pp. 130-138.

Armstrong D. (2002), Oxidative stress biomarkers and antioxidant protocols, Humana Press, Totowa.

Atchibri A.L.O.A, Kouakou T.H., Brou K.D., Kouadio Y.J., Gnakri D. (2010), Evaluation of bioactive components in seeds of Phaseolus vulgaris L. (fabaceae) cultivated in Côte d'Ivoire, Journal of Applied Bioscience, 31, pp. 1928-1934.

Becker E.M., Nissen L.R., Skibsted L.H. (2004), Antioxidant evaluation protocols: food quality or health effects, Eur. Food Res. and Technol., 219(6), pp. 561-571.

Butyrskaya Ye. (2011), Kompyuternaya khimiya: osnovy teoriyi i rabota s programmami Gaussian i Gauss View, Moscow.

Chekman I. (2000), Klinichna fitoterapiya. Pryroda likuye, Kyiv.

Chuyeshov V., Zaytsev O., Shebanova S., Chernov M. (2002), Promyshlennaya tekhnologiya lekarstv, 1, Kharkov.

Dadali V., Makarov V. (2003), Biologicheski aktivnye veschestva lekarstvennykh rasteniy kak faktor detoksikatsiyi organizma, Vorposy pitaniya, 5, pp. 49-55.

Danylova L., Berezka T., Demydova A., Boyko M., Arutyunian T. (2016), Antyoksydant z kory duba yak dzherelo polifenoliv u pyvovarinni, Visnyk Natsionalnoho tekhnichnoho 


\section{Food Technology}

universytetu "Kharkivsky polirekhnichnyi instytut", seriya: Innovatsiyni doslidzhennya u naukovykh robotakh studentiv, 29, pp. 66-71.

Dekebo A. (2021), Plant Extracts, Available at: https://www.intechopen.com/books /plantextracts/introductory-chapter-plant-extracts.

Gordiyenko A. (2000), Vliyaniye rastitelnykh gepatoprotektornykh substantsiy na membranno-metabolicheskuyu aktivnost organell kletok pecheni, Zhurnal AMN Ukrayiny, 3, pp. 587-592.

Gordon M.H., Ail J. (1994), Antioxidant activity of flavonoids isolated from licorice, Int. News Fats, Oils and Relat. Mater, 4, pp. 519-577.

Gromovaya V., Shapoval G., Mironyuk I. (2008), Antioksidantnye svoystva lekarstvennykh rasteniy, Khimiko-farmatsevticheskiy zhurnal, 42(1), pp. 26-29.

Harborne J.B. et al. (2001), Anthocyanins and other flavonoids, Natural Product Reports, 18, pp. 310-333.

Hässig A., Liang W.X., Schwabl H., Stampfli K. (1999), Flavonoids and tannins: plantbased antioxidants with vitamin character, Med. Hypotheses, 52(5), pp. 479-481.

Inglett G.E., Chen D., Berhow M., Lee S. (2011), Antioxidant activity of commercial buckwheat flours and their free and bound phenolic compositions, Food Chemistry, 125(3), pp. 923-929.

Ishiguro K., Yahara S., Yoshimoto M. (2007), Changes in polyphenolic content and radicalscavenging activity of sweet potato (Ipomoea batatas L.) during storage at optimal and low temperatures, J. Agr. and Food Chem. 2007, 55(26), pp. 10773-10778.

Juntachote T., Berghofer E. (2005), Antioxidative properties and stability of ethanolic extracts of Holy basil and Galangal, Food Chem., 92(2), pp. 193-202.

Kähkönen M.P., Hopia A.L., Vuorela H.J. et al. (1999), Antioxidant Activity of Plant Extracts Containing Phenolic Compounds, J. Agr. and Food Chem., 47(10), pp. 3954-3962.

Kjersti A. (2004), Analysis of flavonoids and other phenolic compounds using high performance liquid chromatography with colorimetric array detection: relation to antioxidant activity, J. of Agricultural and Food Chemistry, 52(15), pp. 4594-4603.

Ko Min-Jung, Cheigh Chan-Ick, Cho Sang-Woo, Chung Myong-Soo (2011), Subcritical water extraction of flavonol quercetin from onionskin, J. Food Eng., 102(4), pp. 327-333.

Lashen A., Bortnikov M., Karmanov A. (2007), Antioksidantnye svoystva produktov rastitelnogo proiskhozhdenya, Khimiya rastitelnogo syrya, 2, pp. 79-83.

Levitskyi A. (2001), Bioflavonoidy kak regulyatory fiziologicheskikh funktsiy, Visnyk stomatologiyi, 1, pp. 71-76.

Mazza G., Miniati E. (1993), Anthocyanins in fruits, vegetables and grains, CRC Press Inc., Boca Raton.

Menshieva Ye., Zenkov N. (1994), Biokhimiya okislitelnogo stressa (oksidanty $i$ antioksidanty), Novosibirsk.

Miwa S., Beckman K.B., Muller F.L. (2008), Oxidative stress in aging: from model systems to human diseases, Humana Press, Totowa.

MOZ (2017), Pro zatverdzhennya Norm fiziolohichnykh potreb naselennya Ukrayiny v osnovnykh kharchovykh rechovynakh i enerhiyi. Nakaz Ministerstva okhorony zdorovya vid 03.09.2017 r., Available at: https://zakon.rada.gov.ua/laws/show/z1206-17\#n14.

Nagendran B., Kalyana S., Samir S. (2006), Phenolic compounds in plants and agriindustrial by-products: Antioxidant activity, occurrence, and potential uses, Food Chemistry, 99(1), pp. 191-203.

Petrova V. (1986), Biokhimiya dikorastuschikh plodovo-yagodnykh rasteniy, Kyiv.

Pezzani R., Salehi B., Vitalini S et al. (2019), Synergistic Effects of Plant Derivatives and Conventional Chemotherapeutic Agents: An Update on the Cancer Perspective, Medicina (Kaunas), 55(4), pp. 110-120. 
Robert R., Gorena T., Romero N., Sepulveda E., Chavez J., Saenz C. (2010), Encapsulation of polyphenols and anthocyanins from pomegranate (Punica granatum) by spray drying, Int. J. of Food Sci. and Technol., 45(7), pp. 1386-1394.

Rozek A., Achaerandio I., Guell C., Lopez F., Ferrando M. (2010), Use of commercial grape phenolic extracts to supplement solid foodstuff, LWT - Food Sci. and Technol., 43(4), pp. 623631.

Samotyja U., Majecka M. (2007), Effects of blackcurrant seeds and rosemary extracts on oxidative stability of bulk and emulsified lipid substrates, Food Chemistry, 104(1), pp. 317-323.

Sampiyev A., Litvinenko V., Popova T., Ammosov A. (1999), Prirodnye kompleksy bioflavonoidov i saponinov, Soobschenie 2. Osobennosti izvlecheniya iz rastitelnogo syria (1), pp. 115-118.

Santos D., Saraiva J.M.A., Vicente A., Moldão-Martins M. (2019), Methods for determining bioavailability and bioaccessibility of bioactive compounds and nutrients, Innovative Thermal and Non-Thermal Processing, Bioaccessibility and Bioavailability of Nutrients and Bioactive Compounds. Woodhead Publishing Series in Food Science, Technology and Nutrition, pp. 23-54.

Saura-Calixto F., Goni I. (2006), Antioxidant capacity of the Spanish Mediterranean diet, Food Chemistry, 94(3), pp. 442-447.

Shestopal G. (2011), Antyoxydantna zdatnist biolohichno aktyvnykh rechovyn plodiv yahidnykh kultur, Visnyk Lvivskoyi komertsiynoyi akademiyi, 12, pp. 127-131.

Shkarina Ye., Maksimova T., Nikulina I. (2010), O vliyaniyi biologicheski aktivnykh veschestv na antioksidantnuyu aktivnost fitopreparatov, Khimikp-farmatsevticheskyi zhurnal, 35, pp. $40-47$.

Simakhina G. (2011), Bioflavonoidy u systemi zakhystu biolohichnykh struktur, Naukovi pratsi NUHT, 37-38, pp. 103-109.

Simakhina G. (2012), Polucheniye pischevykh krasiteley iz zelenoy massy rasteniy, Tsukor Ukrayiny, 2, pp. 36-44.

Simakhina G., Khalapsina S. (2016), Biokompleks dykorosloyi syrovyny yak komponent funktsionalnykh produktiv dlya spetskontyngentiv, Kharchova promyslovist, 19, pp. 25-30.

Smolyar V. (2005), Kharchova ekspertyza, Kyiv, Zdorovya.

Solovyov M.Y., Solovyov M.M. (2005), Kompyuternaya khimiya, Moscow, Solon Press.

Spirichev V. (2003), Vitaminy-antioksidanty v profilaktike i lecheniyi serdechnososudistykh zabolevaniy, Voprosy pitaniya, 6, pp. 45-51.

Stetsenko N., Simakhina G., Khalapsina S. (2016), Doslidzhennya antyoksydantnykh vlastyvostey antotsianiv yak neobkhidnykh komponentiv kharchovykh produktiv $\mathrm{v}$ ekstremalnykh umovakh zhyttediyalnosti, Naukovi pratsi NUKHT, 22(4), pp. 167-175.

Sun J., Chu Y.F., Wu X., Liu R.H. (2002), Antioxidant and antiproliferative activities of common fruits, J. of Agricultural and Food Chemistry, 50(25), pp. 7449-7454.

Timirkhanova G., Abdullina G., Kulagina I. (2007), Vitamin C: klassicheskiye predstavleniya i novye fakty o mekhanizmakh biologicheskogo vozdeystviya, Vyatskyi meditsynskiy vestnik, 4, pp. 158-161.

Toor R.K., Savage G.P. (2006), Changes in major antioxidant components of tomatoes during post-harvest storage, Food Chem., 99(4), pp. 724-727.

Ukrayinets A., Simakhina G., Naumenko N., Kaminska S. (2019), Zamorozheni plodovoyahidni napivfabrykaty: yakist, bezpeka, efektyvnist, Stal, Kyiv.

Van Acker S.A., Van Balen G.P., Van den Berg D.I. (1998), Structural aspects of antioxidant activity of flavonoids, J. Biochem. Pharmacol., 56(8), pp. 935-943.

Van der Sluis A.A., Dekker M., Verkerk R., Jongen M.F. (2000), An improved, rapid in vitro method to measure antioxidant activity. Application on selected flavonoids and apple juice, J. of Agricultural and Food Chemistry, 48(9), pp. 4116-4122.

Viskupicova J., Danihelova M., Ondrejovic M., Liptaj T., Sturdik E. (2010), Lipophilic rutin derivatives for antioxidant protection of oil-based foods, Food Chemistry, 123(1), pp. 45-50. 
Voskresensky O.N., Levitsky A.P. (2002), QSAR aspects of flavonoids as a plentiful source of new drugs, Current Medical Chemistry, 9(14), pp. 1367-1383.

Wang J. et al. (2007), Free radical and reactive oxygen species scavenging activities of peanut skins extract, Food Chemistry, 104(1), pp. 242-250.

WHO (1998), Quality control methods for medicinal plant materials, World Health Organization, Geneva

WHO (2004), Quality assurance of pharmaceuticals. A compendium of guidelines and related materials, 2, World Health Organization, Geneva,

Wills R.B.H., Bone K., Morgan M. (2000), Herbal products: active constituents, modes of action and quality control, Nutrition Research Reviews, 13, pp. 47-77.

Yordanov N., Alekseyeva K., Mansour I. (2005), Improvement of the EPR detection of irradiated dry plants using microwave saturation and thermal treatment, Radiation Physics and Chemistry, 73(1), pp. 55-60. 